\title{
Analysing the relationship between Banks' Deposit Interest Rate and Deposit Mobilisation: Empirical evidence from Zimbabwean Commercial Banks (1980-2006)
}

\author{
Tafirei Mashamba ${ }^{1}$, Rabson Magweva ${ }^{2}$, Linda C. Gumbo ${ }^{3}$ \\ 1. Department of Banking \& Finance, Great Zimbabwe University, Zimbabwe \\ 2. Department of Banking \& Finance, Great Zimbabwe University, Zimbabwe \\ 3. Department of Banking \& Finance, Great Zimbabwe University, Zimbabwe
}

\begin{abstract}
This study sought to analyse the relationship between banks' deposit interest rates and deposit mobilisation in Zimbabwe for the period 2000-2006. We developed an Ordinary Least Squares (OLS) model to show the relationship between the response and explanatory variables. Pearson's correlation coeffient $(R)$ was employed to demonstrate the strength of the relationship. Before running the regression equation the data was first tested for; stationarity using the Augmented Dicker-Fuller Test, multicollinearity using correlation matrix and autocorrelation using the Durbin-Watson statistic. The study found a positive relationship between deposit rates and banks' deposits for the period under study and all the other explanatory variables were statistically significant. Also, the coefficient of determination $\left(R^{2}\right)$ was found to be significantly high showing that the explanatory variables were able to account for the total variation of the dependent variable - deposits.

The study recommended banks to tap into the unbanked markets through massive branch expansion, offering low cost accounts and increasing interest offered on deposits to attract more deposits. The government should come up with consistent policies and create a conducive political environment for business and foreign direct investment.
\end{abstract}

Key Words: Deposit Interest Rate, Deposit Mobilisation, Unit Root test, Correlation analysis, Zimbabwe

\section{Introduction}

Lack of confidence in the aftermath of the 2003/4 domestic banking crisis that claimed big players like Trust Bank, Time Bank and Royal Bank, has often been sighted as the driving force behind a crippling depositor fatigue that has ravaged banks. Recently, in July 2012 for the second time Royal Bank surrendered its licence amid revelations that the bank had been involved in serious abuse of depositors' funds and was burdened by non-performing insider loans among a cocktail of operational irregularities. The bank's closure fell hard on the heels of Interfin Bank's placement under curatorship and Genesis Investment bank voluntary surrender of its banking licence after failing to meet minimum capital thresholds. This has driven most individuals to prefer home based savings to banks. The Finscope 2011 Zimbabwean survey concurs that $27 \%$ of Zimbabweans save at home. Moreso, unofficial statistics predict that an estimated $\$ 3$ billion is circulating outside the formal banking system.

Notwithstanding significant strides made in stabilizing the economy, the multiple currency era has been epitomized by transitory deposits in the banking sector, short term loans, market illiquidity and lack of money market instruments. Additionally, the increase in cash based transactions, financial disintermediation, settlement risk and asset quality vulnerability remain worrisome.Concomitantly, indiscipline in the banking sector has once again reared its ugly feet. This is evidenced by increased abuse of depositors' funds as well as the endemic over stepping of operational mandates by money lending institutions. Indeed history is repeating itself as the current challenges faced by the banking sector are reminiscent of the episodes experienced over the period 2003-2004.

One of the reasons often cited for the country's low saving ratio is that banks lack alternative high return investments on deposits (African Economic Outlook, 2012). Nominal lending rates have remained very high averaging 22\% against deposit rates of below $4 \%$ in 2012 (RBZ, MPS January 2013). The low deposit rates coupled with high bank charges are not conducive to attracting savings. On the other hand, the relatively high lending rates discourage borrowing by the productive sectors, thereby inhibiting the growth of the economy. It has been ascertained that for a person earning around US $\$ 200$ per month, and making two withdrawals from the bank incurs bank charges amounting to $15 \%$ of the total deposit, which is a high tax on depositors, (RBZ, MPS July 2012). Following this market failure, regulators came up with a number of raft measures in 2013 to address these anomalies. Among them is the paying of $4 \%$ per annum on deposits above $\$ 1000,00$ kept for 30 days and above.

On the other hand, statistics from the central bank reveal that deposits have grownfrom $\$ 1,4$ billion in December 2009 , to peak close to $\$ 4,5$ billion by the end of 2012 , reflecting a rise of more than $300 \%$ as shown below. 
Fig 1: Bank deposits, Loans and Advances (US\$ millions)

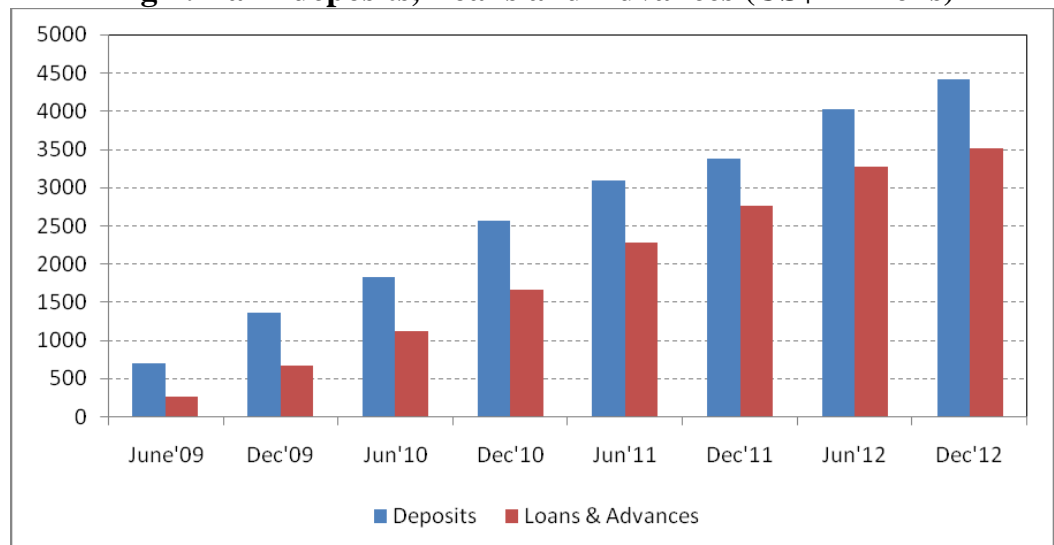

Source: RBZ Monetary Policy January 2013.

Growth in banking sector deposits was largely driven by annual increases in time deposits of over 30-day, 96.18\%; under 30-day, 13.54\%, (RBZ, MPS July 2012). The significant increase in time deposits partially reflects the shifting of economic agents from non-interest earning balances to interest earning deposits. This is because banks have been quoting demand and savings rates that are below $4 \%$ whilst time deposits attracted rates quoted were as high as $22 \%$.

Although deposits have been growing, they have remained relatively short term in nature and financial intermediation is growing slowly, thus depriving the economy of the much needed long term capital for capital expenditure and retooling (Mverecha, 2011).

The disparity between lending and deposit rates in Zimbabwe is widening, dampening the already weak savings culture in the country and its economic recovery, according to the African Development Bank (AfDB Report, 2011). A lot of people have excluded themselves from the banking sector. They feel that physically handling their own money offers them a sense of control given the banking sector's recent history which has caused many a customer bouts of financial anxiety. Faced by the stimuli of both industry competition and regulatory pressure, banks have started to take action. Lately, the market has begun to see a number of new savings products.

In early July 2012, CBZ Bank Limited introduced the CashPlus Savings Account which they tout as a high interest account with no service fees, no withdrawal fees and no maintenance costs.

In April 2012, FBC Bank introduced the Pfimbi/Isiphala Savings Account which earns interest on a monthly basis and does not attract any bank charges.

POSB also came up with the following products; Junior Save, SmartSave and EasySave. JuniorSave and SmartSaveare targeted at the teenagers and toddlers respectively, whom it seeks to teach the importance of saving, hence the minimum deposit amount of $\$ 5$ for both products. EasySave is a fixed-term account under which one makes a once-off investment and chooses a term that suits them from one, two, three, six or 12 months. The minimum deposit is much higher at $\$ 100$ as this account also caters for clubs and societies in addition to individuals. Benefits for all three accounts include tax-free interest and waiver of monthly service fees.

The big question is whether this proliferation of savings accounts will make a difference? If it does, what is its likely impact on deposit mobilisation by banks? This study sought to examine the causal relationship between interest rate offered on deposits and deposit mobilisation by commercial banks in Zimbabwe.

The rest of the paper is organised as follows. Section 2 presents a review related literature. Sections 3 allude to the Research Methodology, while Section 4 Presents and analyse the results. Section 5 draws Conclusion and makes Recommendations (for policy makers and future researches).

\section{Literature Review}

Deposit mobilisation is defined by Elser et al (1999) as the process of encouraging customers to deposit cash with the bank or luring new clients to come and open accounts with the bank. From an institutional perspective, the primary motive for mobilizing savings lies in lower cost of capital compared to other sources of funds.

According to Kutanet al (2010) banks serve as intermediaries accepting commercial and individual deposits (savings) and transferring them in the form of loans to investments. Since the adoption of the multiple currencies in 2009 local banks went on a massivedeposit mobilisation drive by offering a range of products and services that are tailored to their particular clientele which saw them pool substantial amounts from the depositors 


\subsection{Types of deposit accounts}

\subsubsection{Basic Savings}

According to Yang (2009), bank savings accounts have traditionally been one of the simplest and most convenient ways to save. These accounts typically have the lowest minimum deposit requirements and the fewest withdrawal restrictions. But they often pay the lowest interest rates of any of the savings alternatives. Singh (2010) proposessubstantial interest rateson deposits for banks to lure more deposits in a competitive environment. However this strategy of high deposit rates according to Kraft (2000) may fail to work in newly liberalised economies with weak regulations. In his Croatian studies he found that most risk loving banks used high deposit rates to mobilise deposits, by so doing subjecting them to increased bank asset risk. As the bad loans went into default a banking crisis was ignited.

\subsubsection{Money Market Accounts}

These are similar to savings accounts, but may pay higher interest rates. However, they tend to have higher balance requirements than savings accounts, and different interest rates may apply to different account balances. For example, there may be one rate for balances below $\$ 1,000$ a higher rate for balances above say $\$ 5,000$. In addition, you may need a larger deposit to open a money market account.

\subsubsection{Money Market Mutual Funds}

According to Yang (2009) money market mutual funds are similar to money market accounts in many ways. They typically pay interest at about the same rate and many offer cheque-writing privileges. One drawback of money market mutual funds is that money market funds, unlike money market accounts, are not insured by government.

\subsubsection{Certificates of Deposit (CDs)}

In their basic form, (CDs) are time deposits. In a typical CD the bank accepts your deposit for a fixed term-usually a pre-set period from six months to five years and pays you interest until maturity. At the end of the term you can cash in your CD for the principal plus the interest you've earned, or roll your account balance over to a new CD. But you must inform the bank your roll over position before the CD matures. Otherwise the bank may automatically roll over your CD to a new $C D$ with the same term at the current interest rate. And you might earn a better interest rate with a CD that has a different term, or one offered by a different bank.

\subsubsection{Cheque or Current Account}

Singh (2010) defines a cheque or current account as a transactional deposit account held at a bank that allows for withdrawals and deposits. Elser et al (2005) elaborate that money held in a cheque or current account is very liquid, and can be withdrawn using cheques, automated cash machines and electronic debits, among other methods. A cheque account differs from other bank accounts in that it often allows for numerous withdrawals and unlimited deposits, whereas savings accounts sometimes limit both. Current accounts can include business accounts, student accounts and joint accounts along with many other types of accounts which offer similar features.

\subsubsection{Demand Deposit Account (Call Account)}

A Demand Deposit Account as put forward by Yang (2009) is an account from which deposited funds can be withdrawn at any time without any notice to the depository institution. This account allows you to "demand" or "call" your money at any time, unlike a term deposit, which cannot be accessed for a predetermined period.

\subsection{Savings behaviour Theories}

Existing literature to date presents three major theories behind savings: Life cycle hypothesis (Modigliani \&Brumberg, 1954), Permanent Income hypothesis (Friedman, 1957) and the Buffer stock hypothesis (Deaton, 1991).

The life cycle hypothesis is an extension to the Keynes (1936) Absolute income hypothesis. It emphasise that the main motive of saving is retirement accumulation. The theorem views consumption in any given period as a function of future expectations lifetime income. As income fluctuates over an individual's life span, saving behaviour is greatly influenced by one's stage in the life cycle. As such it's anticipated that individuals smoothen consumption over their lifetimes such that they save during their working years and consume upon retirement (Ozcan, Gunney\&Ertac, 2003).

The Permanent income hypothesis attempts to differentiate between permanent and transitory income as the determinants of private savings. Changes in income perceived by households to be permanent tend to reduce 
current savings because they can justify higher consumption today and in the future. On the other hand, income changes perceived to be transitory induce smoothing consumption, whereby today's income is saved for tomorrow's higher consumption.

In its basic from, the Buffer stock hypothesis of savings behaviour proposes that consumers accumulate assets to hedge against unpredictable income fluctuations. Its anticipated that whenever wealth is above a certain target, consumers tend to spent more and save little, while, when current wealth is lower than the perceived target, individuals become prudent leading to higher savings.

\subsection{Relationship between savings rates and deposit mobilisation}

Domestic savings comprise of public and private savings. To encourage private savings, the real interest rates should be positive. Furthermore, innovative saving schemes and investment bonds should be introduced to mobilize resources. These savings are ultimately channelled to the productive sectors of the economy and this promotes economic growth. In light of this McKinnon (1973) and Shaw (1973) hypothesis that countries with repressed financial system find it hard to raise deposits as interest rates on deposits are controlled by the government, hence the need for financial liberalisation. They showed that financial liberalization led to higher interest rates which equated the demand and supply of savings. The authors expressed their view that higher interest rates lead to increased savings and financial intermediation in improving the efficiency of savings and investment. The higher real interest rates increase the extent of financial intermediation which in turn raises the rate of economic growth in developing countries (Balassa, 1989). The growth of any economy depends on capital accumulation, and this requires investment and an equal amount of saving to match it (Thirlwall, 2004).

Considerable regulatory reforms were introduced in Pakistan over the last two decades. Investment and import licensing, and most of the foreign exchange restrictions were removed, capital market regulations were simplified, price and credit controls were relaxed, and interest rates were deregulated (Kemal, 2002).

The financial reforms are likely to bring about considerable economic benefits, particularly through more effective mobilization of domestic savings and by efficient allocation of resources. Domestic savings had a very prominent role in order to sustain the growth of an economy because of increased external financial rigidity (Kasekende, et al. 1999).

The positive impact of real interest rate and real money balances on output growth rate exists which demonstrates the validity of McKinnon Shaw Hypothesis about financial liberalization. The results have no structural break and show positive effect of real balances on output growth of Sri Lanka's economy due to financial liberalization (Ghatak, 1997 ).

Interest rate reforms in Nigeria, a policy under financial sector liberalisation, were to achieve efficiency in the financial sector and engendering financial deepening. In Nigeria, financial sector reforms began with the deregulation of interest rates in August 1987 (Ikhide and Alawode, 2001). Prior to this period, the financial system operated under financial regulation and interest rates were said to be repressed.

According to McKinnon (1973) and Shaw (1973), financial repression arises mostly when a country imposes ceiling on deposit and lending nominal interest rates at a low level relative to inflation. The resulting low or negative interest rates discourage saving mobilisation and channelling of the mobilised savings through the financial system. This has a negative impact on the quantity and quality of investment and hence economic growth. Therefore, the expectation of interest rate reform was that it would encourage domestic savings and make loanable funds available in the banking institutions.

But, the criticism had been that the "tunnel-like" structure of interest rate in Nigeria was capable of discouraging savings and retarding growth in view of the empirical link between savings, investment and economic growth (Ojo, 1976). The critical question, therefore, was whether real interest rates have any positive effect on economic growth in Nigeria. This is important because the behaviour of interest rates, to a large extent, determines the investment activities and hence economic growth of a country.

The main focus of every financial system is financial intermediary, that is, mobilising financial resources from the surplus sector and lend to the deficit outlets to facilitate business transactions and economic development based on the monetary and fiscal policy of the nation. The attraction for getting the deposit from the surplus sector is interest payment, which must be reasonable and acceptable to the owner of the money. Conversely, the attraction for granting credit facility by the bank is interest payment for the use of credit by the borrowers in consideration for parting with liquidity by the lenders. Therefore interest rate dictates both the level of deposit and the amount of credit being offered by the banks.

However, in the African context financial liberalisation proved to be a failure, as it failed to leave to its expectations. Honohan\& Beck (2007) argue that financial liberalisation leads to capital flight as envisaged by the high ratios of offshore deposits to domestic bank deposits. Upadhyaya (2011) agrees that financial liberalisation in Sub-Saharan Africa failed to perform to its expectations, leaving academics and the corporate world with the main question: why did liberalisation fail? 


\subsection{Empirical Literature}

Nabar (2011) assesses how interest rate affects household savings in Chinese 31 provincial level administrative units between 1996 and 2009. A strong positive correlation between household savings and interest rates was established; suggesting that Chinese save to meet a number of needs e.g. retirement consumption and durables purchases. As such high savings rates enable them to meet their target savings.

Mohan (2012) examined deposit mobilisation by cooperative banks in India. The study showed that cooperative banks should rely on individual's depositors as well as cooperative societies. Their efforts should be oriented towards the mobilisation of more savings and current accounts deposits through continuous publicity, effective marketing management and providing good service to the clients.

Das \& Das (2002) discuss the relationship deposit interest rates and the interest amount. They observed that the method of calculating the interest amount can substantially affect the interest paid. Depositors should take into consideration the interest rate computation over and above the quoted nominal rates. Since $89 \%$ of the customers are depositors, a high degree of transparency is needed in regard to effective rates offered to customers.

Laurenceson (2004) drawing on a panel data of 101 countries between 1994 and 2001 examined the relationship between bank franchise values and deposit mobilisation. Results showed a negative relationship between franchise value and a decrease in deposits; suggesting that increased competition leads to improvements in service quality which tempts households to raise their holdings of savings deposits.

In this regard it can be argued that high interest rate on deposits leads to higher deposits (ceteris paribus). But, is this so in the Zimbabwean context? It is imperative to test this hypothesis in the context of the succeeding methodology.

\section{Methodology \& Data}

This study focuses on the relationship between banks deposit rates and deposits mobilisation for Zimbabwean commercial banks. The model specified follows a log relationship, in order to show the elasticity of the dependent with respect to the explanatory variables. In addition, the reason for taking log is that taking the natural logarithm of a series effectively linearises the exponential trend (if any) in the time series data since the $\log$ function is the inverse of an exponential function.In this regard the following variables are of interest; inflation rates, deposit interest rates, economic growth (GDP), interest rate margins and financial deepening. It follows that;

$$
D E P=f(I N F, D R, F D, I R M, G D P)
$$

Using the Ordinary Least Squares equation we estimate the following equation;

$$
\log D E P=\beta_{0}+\beta_{1} \ln I N F_{t}+\beta_{2} \operatorname{Ln} D R_{t}+\beta_{3} \ln F D_{t}+\beta_{4} \ln I R M_{t}+\beta_{5} \ln G D P_{t}+\mu_{t}
$$

Where: $\ln D e p=$ is the total commercial bank deposits(response variable)

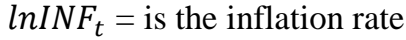

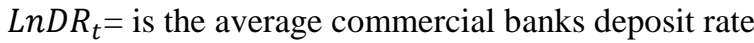

$\ln F D_{t}=$ is the developmentof the banking sector, proxied by M2 to GDPratio

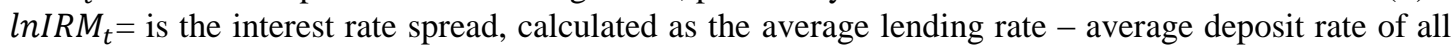
commercial banks

$G D P_{t}=$ is the economic growth rate, proxied by GDP per capita (US\$)

$\beta_{0}=$ is the intercept (constant).

$\beta_{1}, \beta_{2}, \beta_{3}$ and $\beta_{4}$; are coeffients of explanatory variables.

$\mu_{t}=$ is the error term.

$(+/-)=$ expected sign of the explanatory variables.

All the data for this study was obtained from the IMF CD ROM for Zimbabwe statistics. Before running the regression equation the following tests were carried out; stationarity using the Augmented Dickey-Fuller (ADF) test, multicollinearity using the correlation matrix and autocorrelation using the Durbin-Watson (DW) statistic.

\subsection{Unit root test}

\section{Results \& Analysis}

Since time series data was employed, it is important to test for the stationarity of the variables in order to avoid spurious regression. The Augmented Dickey - Fuller test was used for unit root testing. The results of the unit root test for the variables are presented below:

Table 1: Unit Root Test results

\begin{tabular}{|l|c|r|r|r|}
\hline Variable & ADF-statistic & Critical value & Level of significance & Order of integration \\
\hline & -5.529847 & -3.7204 & $1 \%$ & $1^{\text {st }}$ difference \\
& & -2.9850 & $5 \%$ & \\
& & -2.6318 & $10 \%$ & \\
\hline
\end{tabular}


Analysing the relationship between Banks' Deposit Interest Rate and Deposit Mobilisation: Empirical

\begin{tabular}{|c|c|c|c|c|}
\hline DR & -6.081956 & $\begin{array}{r}-3.7204 \\
-2.9850 \\
-2.6318 \\
\end{array}$ & $\begin{array}{r}1 \% \\
5 \% \\
10 \% \\
\end{array}$ & $1^{\text {st }}$ difference \\
\hline INF & -4.953729 & $\begin{array}{l}-3.7204 \\
-2.9850 \\
-2.6318\end{array}$ & $\begin{array}{r}1 \% \\
5 \% \\
10 \%\end{array}$ & $1^{\text {st }}$ difference \\
\hline IRM & -4.010515 & $\begin{array}{l}-3.7204 \\
-2.9850 \\
-2.6318\end{array}$ & $\begin{array}{r}1 \% \\
5 \% \\
10 \%\end{array}$ & $1^{\text {st }}$ difference \\
\hline GDP & -4.612061 & $\begin{array}{l}-3.7204 \\
-2.9850 \\
-2.6318\end{array}$ & $\begin{array}{c}1 \% \\
5 \% \\
10 \%\end{array}$ & $1^{\text {st }}$ difference \\
\hline FD & -6.292706 & $\begin{array}{l}-3.7204 \\
-2.9850 \\
-2.6318\end{array}$ & $\begin{array}{c}1 \% \\
5 \% \\
10 \%\end{array}$ & $1^{\text {st }}$ difference \\
\hline
\end{tabular}

The Unit Root tests showed that all variables where stationary at first differencethe Augmented Dickey- Fuller unit root test statistics are greater than their critical values both at 1\%,5\% and 10\% level of significance. For a variable to be stationery the absolute ADF statistic value should be greater than the critical values given at various percentage levels ignoring the sign. Accordingly, the researchers consider all variables for the estimation of the model.

4.2 Multicollinearity

The results of correlation tests are depicted by a correlation matrix table:

Table 2: Correlation Matrixes

\begin{tabular}{|c|c|c|c|c|c|c|}
\hline & DEP & DR & INF & IRM & GDP & FD \\
\hline DEP & 1.000000 & 0.106010 & -0.528029 & -0.473941 & 0.529068 & 0.308949 \\
\hline DR & 0.106010 & 1.000000 & 0.253799 & 0.396268 & 0.235532 & 0.206677 \\
\hline INF & -0.528029 & 0.253799 & 1.000000 & 0.078770 & -0.438252 & 0.866983 \\
\hline IRM & -0.473941 & 0.396268 & 0.078770 & 1.000000 & 0.140991 & -0.150038 \\
\hline GDP & 0.529068 & 0.235532 & -0.438252 & 0.140991 & 1.000000 & -0.612440 \\
\hline FD & 0.308949 & 0.206677 & 0.866983 & 0.555585 & -0.612440 & 1.000000 \\
\hline
\end{tabular}

The correlation matrix presented in Table 2 indicates a positive relationship between Deposit and Deposit Rate, GDP and Financial Deepening. As expected, Deposits are negatively related to interest rate margins and inflation. All correlations among the dependant and other variables were found to be less than 0.8 ; implying the absence of multicollinearity.

\subsection{Regression Analysis}

Table 3: Summary of Regression Analysis

\begin{tabular}{|l|l|l|l|l|}
\hline VARIABLE & COEFFICIENT & STD ERROR & T STATISTIC & PROB \\
\hline C & -52.71259 & 14.06423 & -3.747989 & 0.0012 \\
\hline LNDR & 0.771615 & 0.399402 & 1.931927 & 0.0670 \\
\hline LNIRM & -1.243923 & 0.318505 & -3.905507 & 0.0008 \\
\hline LNINF & -2.367534 & 0.533948 & -4.434019 & 0.0002 \\
\hline LNGDP & 10.43333 & 2.509055 & 4.158270 & 0.0004 \\
\hline LNFD & 0.980071 & 0.341794 & 2.867431 & 0.0092 \\
\hline
\end{tabular}

$\begin{array}{llll}R^{2} & 0.821316 & \text { Adjusted } R^{2} 0.778772 & \text { F statistic } 19.30519\end{array}$

Prob (F statistic) $0.000000 \mathrm{D}-\mathrm{W}$ statistic 1.868691

4.3.1 Model specified

$\ln D E P=\beta_{0}+\beta_{1} \ln I N F_{t}+\beta_{2} \ln D R_{t}+\beta_{3} \ln F D_{t}+\beta_{4} I R M_{t}+\beta_{5} G D \sim_{t}+\mu_{t}$

$\ln D E P=-52.71259-2.367534 \ln I N F_{t}+0.77161 \ln D R_{t}+0.980071 \ln F D_{t}-1.243923 I R M_{t}$

$$
+10.43333 G D P_{t}+\mu_{t}
$$

\subsection{RESULTS INTERPRETATION}

\subsubsection{Coefficient of Determination}

The above table (Table 3) shows the results of regression analysis. The coefficient of determination $\left(R^{2}\right)$ of 0.821316 means that $82.1316 \%$ of the variation in deposits is being explained by the 
independent variables in the model and there is a strong relationship between deposits and the independent variables. The other less than $1 \%$ is for factors encompassed by the standard error statistic

From the regression results obtained, the model proved to be consistent with the OLS assumption of no autocorrelation. The D-W test of 1.868691 was obtained which is closer to two. Hence the results were not a result of spurious regression.

\subsubsection{Inflation}

The regression coefficient for inflation is -2.367534 . This indicates that ceteris paribus, anincrease in Inflation by $1 \%$ leads to adecrease in deposits by 2.367534 units. Consistent with economic theory, as inflation soars households forego banking products. Households are expected to buy properties and other real assets to cushion themselves against loss in purchasing power of their monies.

\subsubsection{Deposit Rates}

The correlation coefficient for deposit rates is 0.771615 indicating that ceteris paribus a $1 \%$ increase in Deposit Rates leads to a 0.771615 increase in bank deposits. These results are consistent with the findings of Rehmat U.A et al (2010) and Siyanbola T.T (2012). A probability of 0.0670 showed that this variable was significant in assessing the research problem.

\subsubsection{Interest Rates Margin (IRR)}

The coefficient for interest rate margin is -1.243923 indicating that ceteris paribus a $1 \%$ increase in interest margin leads to a 1.243923 increase in commercial bank deposits. This is consistent with the economic theory. The results showed there is a negative relationship between interest rate margin and deposits. High spreads are generally thought to reflect the inefficiencies of a financial system or, as Bernanke (1983) puts it, the costs of financial intermediation. When the spread is too high, it discourages potential savers with low returns. A probability of 0.0008 showed that this variable was significant in assessing the research problem.

\subsubsection{GDP}

Ceteris paribus, a regression coefficient of 10.43333 means that $1 \%$ increase in GDP per capita results in 10.43333 units increase in commercial banks deposits, hence a very strong relationship between deposits and level of economic activity. A key implication of endogenous growth theory is that financial development may affect the steady state rate of economic growth not only by raising the amount of savings channelled to investment and/or raising the social marginal productivity (Pagano, 1993). This was also signified by the probability of 0.0004 , which means the variable is significant.

\subsubsection{Financial Deepening (FD)}

A regression coefficient of 0.980071 means that holding all other variables constant, a percent increase in money supply to GDP ratio (FD) will result in about 0.980071 units increase in commercial banks deposits. This show an existence of a positive relationship between financial deepening and deposits growth and this is consistent with economic theory. Bank deposits represent the most significant components of the money supply used by the public, and changes in money growth are highly correlated with changes in the prices of goods and services in the economy (Kelvin, 2001). Thus an increase in money supply will result in households saving some for future consumption and for investment purposes. Additionally, this can be explained by the probability of 0.0037 which explains that the model is significant.

\section{Conclusions And Recommendations}

This study examined the relationship between savings rates and deposit mobilisation in Zimbabwe. It also investigated other variables that affect bank deposit. Secondary data was adopted for this study covering the period 1980 to 2006. The results of the study showed that all the explanatory variables were statistically significant. Also, the coefficient of determination $\left(R^{2}\right)$ was significantly high, hence the explanatory variables were able to account for the total variation of the dependent variable - deposits. The value of Durbin-Watson Statistic (DW) showed that there was no presence of autocorrelation; hence, the model produced a parsimonious result. The study revealed that the banking sector plays significant roles in the sustenance of growth and development in an economy. The role of savings cannot be over-emphasised in banking credit allocation as saving represents that part of income that has not been consumed and when utilized for capital investment, it increases productivity. Because of the fact that the real sector is indispensable, nominal sector is paramount as its inefficiency is capable of destabilising the whole system of the economy.

Thus, it was concluded that deposit interest rate is an important determinant of deposit mobilisation in Zimbabwe. There exists a positive relationship between the two variables. Hence an increase in savings products with a higher return can positively affect deposit growth in Zimbabwe. The researchers therefore came to a 
conclusion that Zimbabwean banks can pool back funds into the formal banking system if they innovate savings products with attractive returns. However interest rates reforms in Zimbabwe may not optimally achieve its goals, if those other factors (e.g. inflation, interest rate margin, bank failure, high unemployment, liquidity crunch) which negatively affects deposits in the country, as suggested by Muza (2012), are not tackled. This implies that the link between deposit rates and deposit mobilisation is not automatic.

Based on the research findings and conclusions above, the following are recommended for banks in Zimbabwe to mobilize more deposits:

$\checkmark$ Since the main source of funds for commercial banks is deposit banks should give due emphasis to its deposits and strive to increase it.

$\checkmark$ Banks should increase their deposit interest rates in order to mobilise deposits since there exists a positive relationship between savings and deposit interests rates.

$\checkmark$ Banks must come up with products and services for the unbanked population. This could take the shape of low cost accounts, reduced bank charges and interest on deposits. They can also increase their branch networks by moving into the rural areas and other unbanked groups of the economy.

$\checkmark$ Banks should provide excellent services for their customers to mobilize more deposits. Thus banks can promote their products and built brand loyalty.

$\checkmark \quad$ There should be determined effort by the monetary authorities to bridge the widening gap existing between lending rate and savings rate, so that the people will be fully motivated to save in a bid to generate needed loanable funds for investment in Zimbabwe.

$\checkmark \quad$ There is need for government to pursue financial sector development because financial deepening will encourage increase in deposits. When the size of saving is increased, enough bank loans will be available for both the private and public sector which will enhance economic growth hence increasing GDP per capita which

$\checkmark$ The government ought to take steps that ensures address the high rates of unemployment. It has been proved that economic growth is good for the growth of the banking sector. As more people are employed they will take up banks' products. Banks through their intermediatory roles will rechannel the same resources to the economy.

$\checkmark \quad$ In addition, politicians must work in harmony and come up with consistent policies that attract foreign direct investment necessary for economic growth.

\section{References}

[1]. African Development Bank Report, Zimbabwe Monthly Economic Review, October 2011

[2]. Balassa, B. (1989), "Financial Liberalization in Developing Countries", Policy, Planning and Research working papers, World Bank

[3]. Brumberg, R \& Modigliani, F. (1954), "Utility analysis and the consumption function. An interpretation of cross-sectional data", Rutgers University Press

[4]. Das, A \& Das P, (2002), "Rate of interest on term deposits-A micro level study", online publication

[5]. http//:www.math.iitb.ac.in/ ashish/workshop/interest-r4(01-08-02).pdf. accessed 25 February 2013

[6]. Deaton, A. (1991), "Saving and Liquidity Constraints",Econometrica, Vol. 59, No.5 pp 1221-1248.

[7]. Elser, L, et al (1999), "Strict Dollarization and EconomicPerformance: An Empirical Investigation”, Journal of Money, Credit \& Banking, Eschborn, Washington DC.

[8]. FinscopeConsumer Survey Zimbabwe (2011), conducted by Finmark Trust for the Republic of Zimbabwe.

[9]. Friedman M, (1959), "The demand for money: Some theoretical \& Empirical results", Journal of Political Economy, University of Chicago Press.

[10]. Ghatak, S. (1997), "Financial liberalization: The case of Sri Lanka”, Empirical Economics Journal, Vol. 22, pp 117-129.

[11]. Ikhide, SI \&Alawode, A.A (2001), "Financial Sector Reforms, Microeconomic Instability and the Order of Economic Liberation: The Evidence from Nigeria", African Economics Research Paper 112: ISBN 9966-944-53-2.

[12]. Kasekende, L, A. \&Atingi-Ego, M. (1999), "Impact of Liberalization on Key Markets in Sub-Saharan Africa: The Case of Uganda", Journal of International Development, Vol. 11, pp411-436.

[13]. Kemal, A. R. (2002), "Regulatory framework in Pakistan”, The Pakistan Development Review, Vol. 41:4, pp319-332

[14]. Keynes, J.M (1936), "The General theory of employment ,interest\& money”, Harcourt, Brace \& Co. New York and London

[15]. Kraft, E (2000), "The Lending Policies of Croatian Banks: Results of the $2^{\text {nd }}$ CNB Bank Interview project", Croatian National Bank

[16]. Kutan, A.M. et al (2010), "Evaluating the effects of deposit Dollarization in bank profitability" Fordham University, Dealy Hall Bronx, New York.

[17]. Laurenceson, J, (2004), Paper Presented at the International Conference on Industrial Economics \&Regulation, China, 30-31 October 2004.

[18]. Levine. R\&Zervos, S (1998), “Stock markets, Banks \& Economic growth”, American Economic Review, Vol.88 pp 537-58

[19]. Makina D, (2009), "Recovering of the financial sector to building financial inclusiveness", Working Paper 5, UNDP Zimbabwe

[20]. McKinnon, R.I, (1973)“Money and Capital in Economic Development", Brookings Institution, Washington D.C

[21]. Mohan, S (2012), "Perspectives of Deposit Mobilisation," online publication

[22]. http//:www.nabard.org/databank/IARD\%20web/csidfiles/Perspectives\%20Deposits\%20Mobilisation.pdf. Accessed 26 February 2013

[23]. Mverecha, D (2011), "Liquidity Challenges and Way Forward", BAZ Publication.

[24]. Ojo, J.A.T (1976), "The Nigerian Financial System”, University of Wales Press, Cardiff.

[25]. RBZ, "Monetary Policy Statement", January 2013.July 2012 
[26]. Rehmat, U.A et al (2010), "Rate of Interest, Financial Liberalisation \& Domestic Behaviour in Pakistan", Canadian Center of Scince\& Education, Vol.2, No. 4, pp 75-79

[27]. Shaw, E. S. (1973), "Financial Deepening in Economic Development", Oxford University Press, New York

[28]. Siyanbola, T.T et al (2012), "Effect of Interest Rate Deregulation on Banks Deposit Mobilisation in Nigeria", International Journal of Marketing \& Technology, Vol. 2, No. 9, pp 194-202

[29]. Upadhyaya, R (2011), "Analysing the sources and impact of segmentation in the Banking sector: A Case study of Kenya", University of London publications, London, UK

\section{APPENDICES \\ APPENDIX 1: DATA SET}

\begin{tabular}{|c|c|c|c|c|c|c|}
\hline Year & LNIRM & LNDEP & LNGDP & LNINF & LNM2 & LNDR \\
\hline 1980 & 2.640425 & 0.182322 & 5.31709 & 0.262364 & 1.386294 & 0.223144 \\
\hline 1981 & 2.54442 & 0.470004 & 5.364994 & 0.336472 & 1.609438 & 0.356675 \\
\hline 1982 & 2.144956 & 0.641854 & 5.382888 & 0.470004 & 1.609438 & 0.105361 \\
\hline 1983 & 2.33093 & 0.875469 & 5.409053 & 0.587787 & 1.791759 & 0.123108 \\
\hline 1984 & 2.541274 & 1.029619 & 5.420446 & 0.648659 & 2.079442 & 0.09531 \\
\hline 1985 & 1.96361 & 1.131402 & 5.438601 & 0.684521 & 2.302585 & 0.182322 \\
\hline 1986 & 1.000938 & 3.206803 & 5.363824 & 0.788457 & 2.70805 & 0.470004 \\
\hline 1987 & 1.230615 & 3.543854 & 5.364947 & 0.832909 & 2.302585 & 0.641854 \\
\hline 1988 & 1.200216 & 3.962716 & 5.361855 & 0.641854 & 2.302585 & 0.788457 \\
\hline 1989 & 1.422707 & 4.855929 & 5.539104 & 0.686399 & 2.639057 & 0.336472 \\
\hline 1990 & 1.06672 & 5.853638 & 5.506185 & 0.824549 & 2.833213 & 0.470004 \\
\hline 1991 & 0.266203 & 4.923638 & 5.419738 & 0.991759 & 3.871201 & 0.587787 \\
\hline 1992 & 0.766805 & 4.834483 & 5.356445 & 0.252763 & 3.688879 & 0.788457 \\
\hline 1993 & 1.929345 & 5.70237 & 5.372079 & 0.252763 & 2.995732 & 0.832909 \\
\hline 1994 & 2.093098 & 3.35199 & 5.428468 & 0.486294 & 3.218876 & 1.252763 \\
\hline 1995 & 2.176266 & 4.704748 & 5.430047 & 0.498659 & 3.332205 & 1.791759 \\
\hline 1996 & 2.538052 & 3.88707 & 5.635825 & 1.504549 & 2.772589 & 1.206803 \\
\hline 1997 & 2.63536 & 2.312535 & 5.536389 & 1.609438 & 2.995732 & 1.386294 \\
\hline 1998 & 2.564693 & 1.587764 & 5.36845 & 1.609438 & 3.871201 & 1.609438 \\
\hline 1999 & 2.82608 & 1.97553 & 5.370359 & 1.648659 & 4.041295 & 1.609438 \\
\hline 2000 & 2.892684 & 0.510826 & 5.439035 & 1.791759 & 4.011325 & 1.791759 \\
\hline 2001 & 3.181087 & 0.356675 & 5.351194 & 2.079442 & 4.719391 & 1.704748 \\
\hline 2002 & 1.896142 & 0.223144 & 5.30802 & 2.302585 & 5.292953 & 1.88707 \\
\hline 2003 & 1.117003 & 0.356675 & 5.320715 & 2.70805 & 6.394844 & 0.312535 \\
\hline 2004 & 1.168825 & 0.105361 & 5.242699 & 2.302585 & 4.888468 & 0.543854 \\
\hline 2005 & 1.973971 & 0.123108 & 5.14365 & 2.302585 & 6.373047 & 0.162716 \\
\hline 2006 & 1.680457 & 0.09531 & 5.082149 & 2.639057 & 7.155482 & 0.255929 \\
\hline
\end{tabular}

APPENDIX 2: UNIT ROOT TEST

\begin{tabular}{|c|c|c|c|}
\hline ADF Test Statistic & -5.529847 & $\begin{array}{l}1 \% \text { Critical Value* } \\
5 \% \text { Critical Value } \\
10 \% \text { Critical Value }\end{array}$ & $\begin{array}{l}-3.7204 \\
-2.9850 \\
-2.6318\end{array}$ \\
\hline
\end{tabular}

*MacKinnon critical values for rejection of hypothesis of a unit root.

Augmented Dickey-Fuller Test Equation

Dependent Variable: D(LNDEP,2)

Method: Least Squares

Date: 05/02/13 Time: $12: 41$

Sample(adjusted): 19822006

Included observations: 25 after adjusting endpoints

\begin{tabular}{|c|c|c|c|c|}
\hline Variable & Coefficient & Std. Error & t-Statistic & Prob. \\
\hline $\begin{array}{l}\mathrm{D}(\operatorname{LNDEP}(-1)) \\
\mathrm{C}\end{array}$ & $\begin{array}{l}-1.139436 \\
-0.015318 \\
\end{array}$ & $\begin{array}{l}0.206052 \\
0.191806 \\
\end{array}$ & $\begin{array}{l}-5.529847 \\
-0.079862 \\
\end{array}$ & $\begin{array}{l}0.0000 \\
0.9370 \\
\end{array}$ \\
\hline $\begin{array}{l}\text { R-squared } \\
\text { Adjusted R-squared } \\
\text { S.E. of regression }\end{array}$ & $\begin{array}{l}0.570729 \\
0.552065 \\
0.959026\end{array}$ & $\begin{array}{r}\text { Mean d } \\
\text { S.D. de } \\
\text { Akaike inf }\end{array}$ & & $\begin{array}{l}-0.012619 \\
1.432923 \\
2.830821\end{array}$ \\
\hline
\end{tabular}




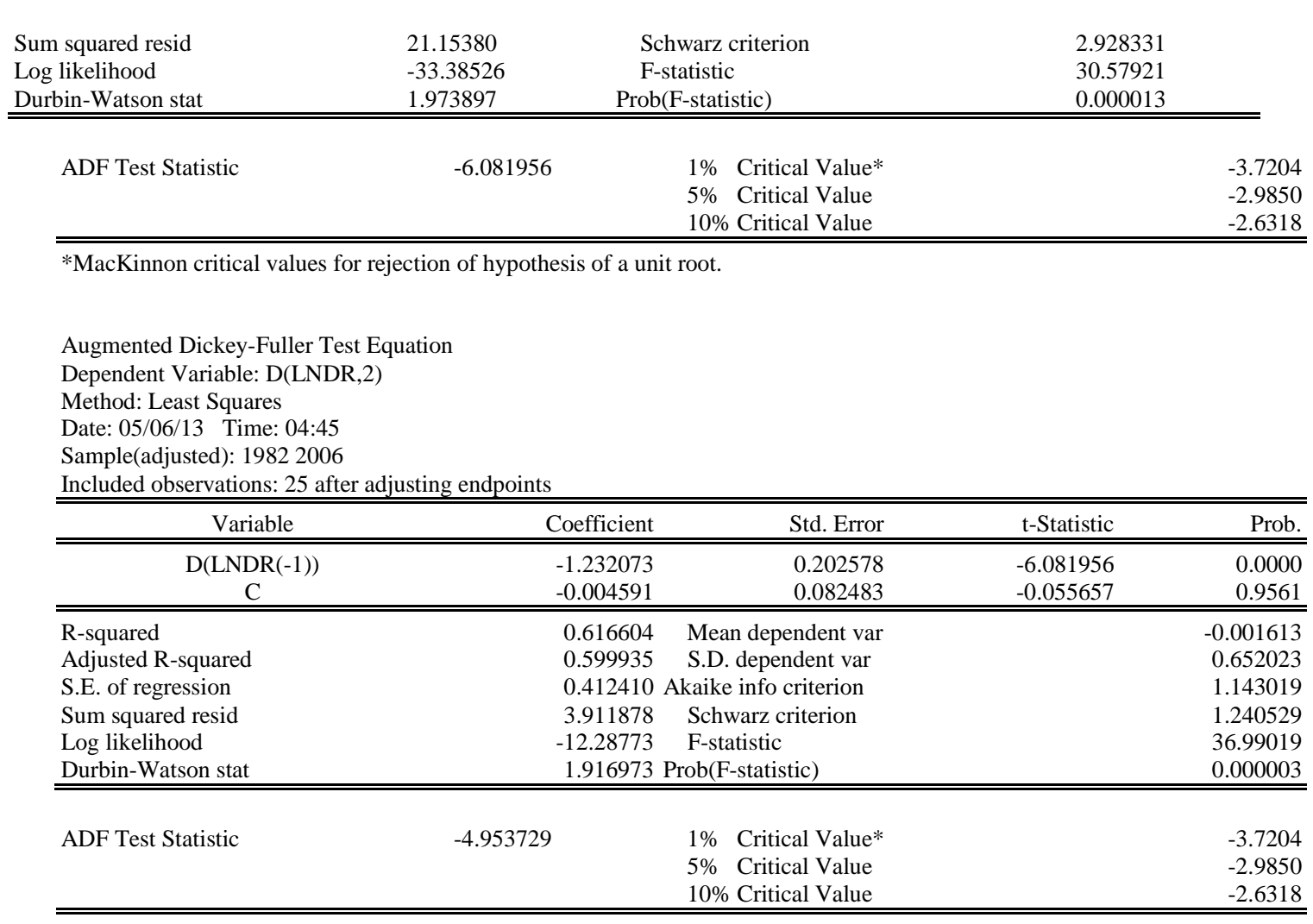

*MacKinnon critical values for rejection of hypothesis of a unit root.

Augmented Dickey-Fuller Test Equation

Dependent Variable: D(LNINF,2)

Method: Least Squares

Date: 05/06/13 Time: 04:47

Sample(adjusted): 19822006

Included observations: 25 after adjusting endpoints

\begin{tabular}{|c|c|c|c|c|}
\hline Variable & Coefficient & Std. Error & $\mathrm{t}$-Statistic & Prob. \\
\hline $\mathrm{D}(\operatorname{LNINF}(-1))$ & -1.047104 & 0.211377 & -4.953729 & 0.0001 \\
\hline $\mathrm{C}$ & 0.095947 & 0.063378 & 1.513900 & 0.1437 \\
\hline R-squared & 0.516191 & Mean dependent var & & 0.010495 \\
\hline Adjusted R-squared & 0.495156 & S.D. dependent var & & 0.429155 \\
\hline S.E. of regression & 0.304925 & Akaike info criterion & & 0.539115 \\
\hline Sum squared resid & 2.138520 & Schwarz criterion & & 0.636625 \\
\hline Log likelihood & -4.738940 & F-statistic & & 24.53943 \\
\hline Durbin-Watson stat & 1.984568 & Prob(F-statistic) & & 0.000052 \\
\hline \multirow[t]{3}{*}{ ADF Test Statistic } & \multirow[t]{3}{*}{-4.010515} & $1 \%$ Critical Value* & & -3.7204 \\
\hline & & $5 \%$ Critical Value & & -2.9850 \\
\hline & & $10 \%$ Critical Value & & -2.6318 \\
\hline
\end{tabular}

*MacKinnon critical values for rejection of hypothesis of a unit root.

Augmented Dickey-Fuller Test Equation

Dependent Variable: D(LNIRM,2)

Method: Least Squares

Date: 05/06/13 Time: 04:47

Sample(adjusted): 19822006

Included observations: 25 after adjusting endpoints

\begin{tabular}{lrrrr}
\hline \multicolumn{1}{c}{ Variable } & Coefficient & Std. Error & t-Statistic & Prob. \\
\hline \multicolumn{1}{c}{ D(LNIRM(-1)) } & -0.827529 & 0.206340 & -4.010515 & 0.0005 \\
C & -0.029961 & 0.110926 & -0.270098 & 0.7895 \\
\hline \hline R-squared & 0.411527 & Mean dependent var & -0.007900 \\
Adjusted R-squared & 0.385942 & S.D. dependent var & 0.706907 \\
S.E. of regression & 0.553946 & Akaike info criterion & 1.733118 \\
Sum squared resid & 7.057680 & Schwarz criterion & 1.830628
\end{tabular}




\begin{tabular}{|c|c|c|c|}
\hline Log likelihood & & F-statistic & 16.08423 \\
\hline Durbin-Watson stat & & $\mathrm{ob}(\mathrm{F}$-statistic) & 0.000548 \\
\hline ADF Test Statistic & -4.612061 & $1 \%$ Critical Value* & -3.7204 \\
\hline & & $5 \%$ Critical Value & -2.9850 \\
\hline & & $10 \%$ Critical Value & -2.6318 \\
\hline
\end{tabular}

*MacKinnon critical values for rejection of hypothesis of a unit root.

Augmented Dickey-Fuller Test Equation

Dependent Variable: D(LNGDP,2)

Method: Least Squares

Date: 05/06/13 Time: 04:48

Sample(adjusted): 19822006

Included observations: 25 after adjusting endpoints

\begin{tabular}{|c|c|c|c|c|}
\hline Variable & Coefficient & Std. Error & t-Statistic & Prob. \\
\hline D(LNGDP(-1)) & -0.959415 & 0.208023 & -4.612061 & 0.0001 \\
\hline $\mathrm{C}$ & -0.011032 & 0.017031 & -0.647790 & 0.5235 \\
\hline R-squared & 0.480474 & Mean dependent var & & -0.004376 \\
\hline Adjusted R-squared & 0.457886 & S.D. dependent var & & 0.115236 \\
\hline S.E. of regression & 0.084847 & kaike info criterion & & -2.019326 \\
\hline Sum squared resid & 0.165576 & Schwarz criterion & & -1.921816 \\
\hline Log likelihood & 27.24158 & F-statistic & & 21.27111 \\
\hline Durbin-Watson stat & 1.977464 & $\operatorname{rob}(\mathrm{F}$-statistic) & & 0.000122 \\
\hline \multirow[t]{3}{*}{ ADF Test Statistic } & \multirow[t]{3}{*}{-6.292706} & $1 \%$ Critical Value* & & -3.7204 \\
\hline & & $5 \%$ Critical Value & & -2.9850 \\
\hline & & $10 \%$ Critical Value & & -2.6318 \\
\hline
\end{tabular}

*MacKinnon critical values for rejection of hypothesis of a unit root.

Augmented Dickey-Fuller Test Equation

Dependent Variable: D(LNM2,2)

Method: Least Squares

Date: 05/06/13 Time: 04:49

Sample(adjusted): 19822006

Included observations: 25 after adjusting endpoints

\begin{tabular}{lrrrr}
\hline \multicolumn{1}{c}{ Variable } & Coefficient & Std. Error & t-Statistic & Prob. \\
\multicolumn{1}{c}{ D(LNM2(-1)) } & -1.282994 & 0.203886 & -6.292706 & 0.0000 \\
\multicolumn{1}{c}{ C } & 0.278291 & 0.129116 & 0.155356 \\
\hline \hline R-squared & 0.632577 & Mean dependent var & 0.022372 \\
Adjusted R-squared & 0.616602 & S.D. dependent var & 0.989545 \\
S.E. of regression & 0.612718 Akaike info criterion & 1.934793 \\
Sum squared resid & 8.634727 & Schwarz criterion & 2.032303 \\
Log likelihood & -22.18492 & F-statistic & 39.59814 \\
Durbin-Watson stat & 2.053698 Prob(F-statistic) & 0.000002 \\
\hline \hline
\end{tabular}

APPENDIX 3: CORRELATION MATRIX

\begin{tabular}{cccrrrr} 
& LNDEP & LNDR & LNGDP & \multicolumn{1}{c}{ LNINF } & \multicolumn{1}{c}{ LNIRM } \\
LNDEP & 1.000000 & 0.106010 & 0.529068 & -0.528029 & -0.473941 & 0.396268 \\
LNDR & 0.106010 & 1.000000 & 0.235532 & 0.253799 & 0.3962949 \\
LNGDP & 0.529068 & 0.235532 & 1.000000 & -0.438252 & 0.140991 & -0.206677 \\
LNINF & -0.528029 & 0.253799 & -0.438252 & 1.000000 & 0.078770 & 0.866983 \\
LNIRM & -0.473941 & 0.396268 & 0.140991 & 0.078770 & 1.000000 & -0.150038 \\
LNM2 & 0.308949 & 0.206677 & -0.612440 & 0.866983 & -0.150038 & 1.000000
\end{tabular}

APPENDIX 4: REGRESSION RESULTS

Dependent Variable: LNDEP

Method: Least Squares

Date: 05/02/13 Time: 12:37

Sample: 19802006

Included observations: 27

\begin{tabular}{lllll}
\hline \hline Variable & Coefficient & Std. Error & t-Statistic & Prob. \\
\hline \hline C & -52.71259 & 14.06423 & -3.747989 & 0.0012 \\
LNDR & 0.771615 & 0.399402 & 1.931927 & 0.0670 \\
LNGDP & 10.43333 & 2.509055 & 4.158270 & 0.0004 \\
LNINFLATION & -2.367534 & 0.533948 & -4.434019 & 0.0002 \\
LNIRM & -1.243923 & 0.318505 & -3.905507 & 0.0008 \\
\hline
\end{tabular}


Analysing the relationship between Banks' Deposit Interest Rate and Deposit Mobilisation: Empirical

\begin{tabular}{llcc} 
LNM2 & 0.980071 & 0.341794 & 2.867431 \\
\hline \hline R-squared & 0.821316 & Mean dependent var & 0.0092 \\
Adjusted R-squared & 0.778772 & S.D. dependent var & 2.252031 \\
S.E. of regression & 0.941657 & Akaike info criterion & 2.002041 \\
Sum squared resid & 18.62108 & Schwarz criterion & 2.910779 \\
Log likelihood & -33.29552 & F-statistic & 3.198743 \\
Durbin-Watson stat & 1.868691 & Prob(F-statistic) & 19.30519 \\
\hline \hline
\end{tabular}

